\title{
RESEÑAS
}

\section{[La colección "Orientaciones en Ciencia, Tecnología Y Cultura": Un cometido}

cultural]

Si puede hablarse de era de la información para designar las últimas décadas del siglo, la más reciente revolución cultural es la del conocimiento. Este no es solamente información. Es, en realidad, información articulada por intereses sociales.

Un mismo dato es para algunos axioma; para otros, teorema. Eso indica que su significado depende del plexo de sus asociaciones. Estas no son universales ni estáticas. Dependen de personas. Sólo las personas configuran conocimiento. Sólo las personas tienen recuerdos y no solamente memoria.

La relatividad del conocimiento es la relatividad inherente al pluralismo derivado de las diferencias entre las personas, alimentadas por intereses distintos, expectativas diversas, capacidades innumerables.

El gran desafío para la difusión de las ciencias y las disciplinas no estriba en la fidelidad con que sus informaciones se transmiten. Consiste, en verdad, en ordenar éstas en cuerpos de conocimiento accesibles a personas distintas. Tal es el verdadero cometido cultural de la divulgación y de la llamada tarea de extensión en el seno de las universidades. Reformular los usos sociales que originaron una forma de conocimiento para producir otra.

Hacer eso evitando la simplificación empobrecedora o la espectacularidad periodística no es tarea sencilla. Exige conocimiento e interés, las dos claves de la cultura. Exige, además, dominio del discurso propio de cada disciplina, pues las disciplinas son esas peculiares imbricaciones de persona y lenguaje que llamamos discursos.

La tarea que se propuso la Editorial Universitaria al crear la colección "Orientaciones en Ciencia, Tecnología y Cultura" fue precisamente ésta: lograr que acreditados especialistas, enfrentados a su propio saber, lo convirtieran en un producto culturalmente polisémico. Que hablaran de lo suyo a otros. Que cruzaran la barrera que los separa de los profanos. Que no hablaran solamente a sus pares. Que fueran "trans-pares", más allá de sus respectivas comunidades de expertos.

Cada autor recibió el encargo de decir en pocas páginas - con esa concisión que demanda madurez y esfuerzo - lo relativo a sus preocupaciones, condensado en una o en un par de palabras. El título de cada libro debiera ser como la entrada de una enciclopedia horizontal: Universo, Depresión, Familia, Bioética, SIDA. Cada volumen interpela un segmento o aspecto de las realidades que construyen los expertos en un registro apto para los no expertos. Al terminar cada libro, el lector 
debe tener una idea de lo mentado en su título, haber acogido una global impresión, estar en condiciones de profundizar más.

Los temas fueron escogidos atendiendo a varios aspectos. Relevantes fueron importancia social, interés fáctico, atracción espontánea. Su desarrollo fue encomendado a personas versadas en ellos que, además, supieran transmitir el entusiasmo del descubrimiento y la sobriedad de sus límites.

La Editorial ha sido en esta empresa fiel su irrenunciable cometido cultural. Crear conocimiento, iniciar procesos sociales asociados al conocimiento, estimular el intercambio de ideas y sentimientos y contribuir a la diversidad razonada de la comunidad hispanohablante.

\section{Fernando Lolas Stepke}

